Perceptual mapping of electronic banking channels in India: A Multidimensional Scaling approach

\author{
Bamoriya, Prerna $\$ \\ Acropolis Faculty of Management \& Research, India (prernasharma@acropolis.in) \\ Bamoriya, Hemant \\ Acropolis Faculty of Management \& Research, India (hemantbamoriya@acropolis.in) \\ Singh, Preeti \\ Devi Ahilya University, India (drpreetisingh@dauniv.ac.in)
}

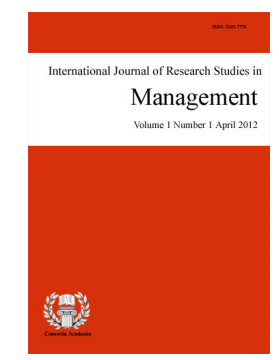

ISSN: $2243-7770$ Online ISSN: 2243-7789

OPEN ACCESS

\title{
Abstract
}

In recent times, intensifying competition and financial liberalization has led Indian banking sector to look towards information and communication technology (ICT). So banks are rapidly adopting electronic banking channels to efficiently reach their target market and reduce operational cost. Despite the various advantages of electronic banking, it is still in infancy stage in India. There is a need to systematically explore customers' perceptions towards various electronic banking channels and their underlying motives to choose \& prefer one channel over other. This study uses Multidimensional Scaling (MDS) approach to develop a perceptual map of select electronic channels and to derive relevant dimensions. Findings suggest that Automated Teller Machine (ATM) is distinctly placed and was perceived to be most secure \& useful electronic banking channel. Internet banking and mobile banking were perceived to be low on security dimension. Phone banking although perceived secure, but it scored high on complexity and low on usefulness. Further, paper presents important implications for bank to improve adoption of electronic banking services.

Keywords: e-banking; ATM; internet banking; mobile banking; phone banking; MDS 


\section{Perceptual mapping of electronic banking channels in India: A Multidimensional Scaling approach}

\section{Introduction}

Last couple of decades witnessed substantial changes in banking system; primarily led by globalization and financial liberalization. Responding to these changes, banking system is continuously expanding the choice of services offered to the customers and increasing their reliance on technology to offer such services (Al-Smadi \& Al-Wabel, 2011). Further, intensified completion is continuously forcing banks to find new markets and expand their customer base. Here again, banks are looking towards information \& telecommunication technology as panacea, so they are rapidly adopting electronic channels to reach their target markets (Al-Smadi, 2012). Electronic banking is a bigger platform than just banking via internet i.e. online banking (Alagheband, 2006). According to Prakash and Malik (2008), electronic banking (further referred as e-banking) is the application of telecommunication technology that enables individuals or business to access accounts, transact, or obtain information on financial products and services. It may include different channels viz. Automated Teller Machine (ATM), Electronic Transfer of Funds (EFT), Internet Banking, Phone Banking, Electronic Clearance System (ECS) (Kolodinsky et al., 2004; Nitsure, 2003).

E-banking demands few internal resources, initially and therefore, lowers the cost. As well as it offers lower operational cost per transaction in comparison to traditional retail banking channel (Chang, 2002; VanHoose, 2003). Further it provides wider availability and possibility to reach more customers. Benefit of 'wider reach' becomes particularly relevant to developing \& underdeveloped countries, where banking system is not fully developed \& substantial population is still unbanked. Specifically in Indian context, approx. 0.6 billion populations are yet to be covered under the formal banking system and India have only 88,000 bank branches. On other hand, there are about 120 million Indians connected to the Internet. Further, 898 million Indians are using mobile phones, 292 million of whom live in rural areas (Jhingan, 2012). Certainly these communication technologies present better opportunity to establish alternative e-banking channels to deliver banking services to all, both cost-effectively and immediately. This benefit is a prominent in case of mobile banking channel in comparison to other e-banking channels like internet, ATM etc. Reason is simple, in developing countries penetration of mobile phones in much greater than internet (Kessler, 2011). From the customers' point of view, this e-banking allows customers easier access to financial services and saves substantial time \& effort in managing their bank accounts (Nitsure, 2003, Anguelov et al., 2004; Almazari \& Siam, 2008; Ayrga, 2011; Al-Smadi, 2012).

Despite the various advantages of e-banking, it is still in its infancy state in many developing countries including India. Here, consumers either do not trust or do not have access to the necessary infrastructure to be able to process e-banking transactions (Nitsure, 2003; Saxena, 2009; Bamoriya, 2010). Many authors have studied e-banking; mainly internet banking from consumers' perspective. These literatures relate to general adoption of e-banking technology, with an emphasis on factors affecting adoption of this new technology by consumers. However, research exploring customers' perceptions towards various e-banking channels and their underlying motives to choose \& prefer one channel over other, is practically none existing.

Identifying the research gap, we tried to develop a perceptual map of various e-banking channels available in India and to derive relevant dimensions which affects above perception. Main idea (from implication point of view) was to derive some useful action points, which could help India banks to promote e-banking. The study is structured as follows: Section 2 review the related literature. Section 3 presents the methodology, and section 4 presents the analysis, findings \& discussion. Section 5 presents the conclusions \& implications of the study. Finally section 6 presents scope for future research followed by limitations of study. 


\section{Literature Review}

Mols et al. (1999) stated that the diffusion of e-banking is more determined by consumer's acceptance than by the bank's offerings. Many authors have studied this consumers' acceptance of e-banking services and, stated various psychographic \& demographic factors affecting it. Calisir and Gumussoy (2008) stated that internet banking, ATM and phone banking substitute each other. They on the basis of empirical research concluded that internet banking is considered to be efficient for ease of use and access. But the users of internet banking lack confidence in the security of the web sites of internet banking.

Sadeghi and Heidarzadeh (2010) opined that adoption of e-banking would be led by customer satisfaction. For this they provided a model on customers' satisfaction of using electronic banking services which comprises select factors viz. convenience, accessibility, bank image, accuracy, security, usefulness. They concluded that these factors illustrate a significant statistical difference according to gender. Similarly Kolodinsky et al. (2004) explored factors affecting intention to adopt three e-banking technologies and changes in these factors over time. They found that relative advantage, simplicity, compatibility, observability, risk tolerance and product involvement are positively associated with adoption of e-banking. They further reported that income, assets, education, gender and marital status, and age also affect e-banking adoption. O'Connell (1996) empirically demonstrated that the explanation for slow adoption of e-banking is caused by security concerns, lack of knowledge about availability of such technical services, being not user friendly and the lack of access to computers and/or internet.

Jasmina and Vlahov (2011) reported that consumers' decision to adopt the e-banking services is significantly affected by their perception of security control over the channel. Gerrard et al. (2006) conducted an empirical study among Singapore bank customers and identified eight characteristics relating to the adoption of internet banking such as social desirability, compatibility, convenience, complexity, confidentiality, accessibility, economic benefits and PC proficiency. They reported complexity, accessibility and PC proficiency as highly influential factors of adoption of e-banking services. Adapa et al. (2009) reported that level of education and level of income within the demographic characteristics were significantly and positively associated to consumers' frequency of internet banking usage.

On the other hand other demographic characteristics such as age, gender, ethnicity, occupation and social dimensions systematically do not relate to the frequency of internet banking usage. Kumar and Garg (2012) conducted model based study on e-banking and reported that ease of contact, efficiency and customer care are major driver of net banking. They suggested that the banks looking to enhance their customer base for net banking usage must address the easiness in use of net banking services and customer contact to solve their problem. Further, Centeno (2004) argued that speed, convenience of remote access, $7 * 24$ availability and price incentives are the main motivation factors for the consumers to use internet banking.

According to Wessels and Drennan (2010) Perceived usefulness, risk, cost and compatibility are the factors which affect consumer acceptance of mobile banking, one of the channels of e-banking. Aladwani (2001) mentioned that security, online banking regulations, privacy and bank's reputation were the most important future challenges of online banking adoption. According to him, potential customers ranked security and privacy as the most important future challenges that banks are facing. Aliyu et al. (2012) suggested that e-banking channels such as internet banking, mobile banking and ATMs should be made as user-friendly as possible, as not many consumers are familiar with the e-banking, especially the older generation. They opined that providing online help and giving customer the choice of their preferred language will increase their perceived ease of electronic transactions.

Joshua and Koshy (2011) studied the various usage patterns of electronic banking services by Indian customers. They surveyed the customers of some of the leading banks in India who are residing in the selected metro and urban banked centers in India. They found that though ATMs have been widely adopted while the 
level of adoption of other electronic banking means like internet banking, phone banking and mobile banking despite their potential are yet to pick in a big way. Bamoriya (2011) stated that the major problem of e-banking is its non-adoption by the customers. They studied the barriers in adoption of mobile banking along with preferred services by the mobile banking customers and influence of demographic variable on mobile banking service adoption. They found that customers' perceived safety is the major reason of not adopting mobile banking services. As far as preferred services were concerned, balance check tops as customers prefer information based services rather than financial services provided by the bank.

Geetha and Malarvizhi (2011) analyzed the factors which are affecting the acceptance of e-banking services among the customers. They reported level of concern regarding security and privacy issues in Indian context. They found that many factors like security, privacy and awareness level increased the acceptance of e-banking services among Indian customers. They reported that if banks provide them necessary guidance and ensure safety of their accounts, customers are willing to adopt e-banking. They concluded that customers are more reluctant to join new technologies or methods that might contain little risk. Hence, banks should design e-banking channels to properly address security and trust issues.

\section{Methodology}

For developing a perceptual map of e-banking services, five active e-banking channels were selected viz. Automated Teller Machine (ATM), Electronic Transfer of Funds (EFT), phone banking, mobile banking \& internet banking. Active channels are those in which customer is completely involved till transaction is over. Passive e-banking channels like Electronic Clearance System (ECS) were not studied; reason is that in such cases once consumers sign up of services, there is nothing else they need to do. Thus in such case customers may not face affective \& cognitive state with e-banking services at fullest (Kolodinsky et al., 2004).

Perceptual mapping is a marketing research tool where products are displayed as points on a map (Kohli \& Leuthesser, 1993). Multidimensional scaling (MDS) is a technique for perceptual mapping which provides a visual representation of the objects (products) in a common space. MDS involves formulation of problem followed by determining appropriate form in which data to be obtained. Subsequently suitable MDS procedure is adopted to analyze the data. An important aspect of the solution involves determining the number of dimensions for perceptual map. Finally, quality of output produced is to be assessed for validity \& reliability (Malhotra \& Dash, 2011).

Five objects i.e. e-banking channels (Automated Teller Machine (ATM), Electronic Transfer of Funds (EFT), phone banking, mobile banking \& internet banking) were studied using perception data - direct approach. This means, respondents were asked to judge level of dissimilarities among select channels using their own criteria. Using judgmental sampling, data from 468 respondents was collected (excluding the cases with high number of outliers and/or missing values). Respondents were the individuals with bank account \& who have used e-banking channels understudy, at least once. Structured questionnaire was used for data collection. Part I of questionnaire was intended to obtain the respondents' perception data i.e. dissimilarity data. For this, total 10 pairs were formed for five objects. These pairs were subject to respondents' rating on 7 point likert scale (1- very similar, 7 very dissimilar) in terms of degree of dissimilarity between two objects. Data was subject to aggregate level analysis using the Alternating Least-Squares Scaling (ALSCAL) algorithm in SPSS17.

Objective in MDS is to have a perceptual map which best fits the data obtained to minimum number of dimensions. Kruskal and Wish (1978) reported that the number of potentially useful dimensions for any data set are given by the equation $\mathrm{D}<$ or $=(\mathrm{K}-1) / 4$, where $\mathrm{D}=$ number of dimensions, $\mathrm{K}=$ number of objects (in this case $\mathrm{K}=5$ ). Using this formula, optimal number of dimensions for this study seems to be two. Further, two dimensional maps are much easy to interpret. Hence, for the study purpose numbers of dimensions chosen were two.

Next, reliability \& validity of MDS output/ perceptual map is to be tested. For this one badness-of-fit index 
and one goodness-of-fit index were applied. S-stress is the most commonly used measure for determining a model's badness-of-fit (Steyvers, 2002). A value of 0.1 or more suggests poor fit in case of 2 dimensional solutions (Blake et al., 2003). On other hand, R- square measure goodness-of-fit and indicates the proportion of variance of the disparities accounted for by the MDS procedure. Although a higher value of R- square is desirable, values of 0.6 or more are considered acceptable (Malhotra \& Dash, 2011).

In MDS, once perceptual map is produced using direct approach: perception data, next important tasks is to label the dimensions with relevant criteria. This task is very subjective in nature where intention is to explore which criteria respondents used to choose their Reponses. For this, first on the basis of extensive literature review some relevant criteria viz. complexity, accessibility, cost, accuracy, security, usefulness, privacy; were identified. Subsequently in part II of questionnaire, respondents were asked to rate select channels on these 7 criteria. Using regression analysis, these 7 criteria vectors were fitted to the perceptual map of select channels. Concept is that the axes may be labeled for the criterion which they most closely align, resulting in labeling of dimensions (Malhotra \& Dash, 2011).

\section{Analysis, Findings \& Discussions}

A Dissimilarity data of 5 objects under study was subject to ALSCAL algorithm to generate perceptual map of e-banking. Measurement level was interval and data matrix shape was symmetric. Further, Euclidean distance was used to scale the map. SPSS17 took 4 iterations to produced initial 2 dimensional solutions (See Figure 1).

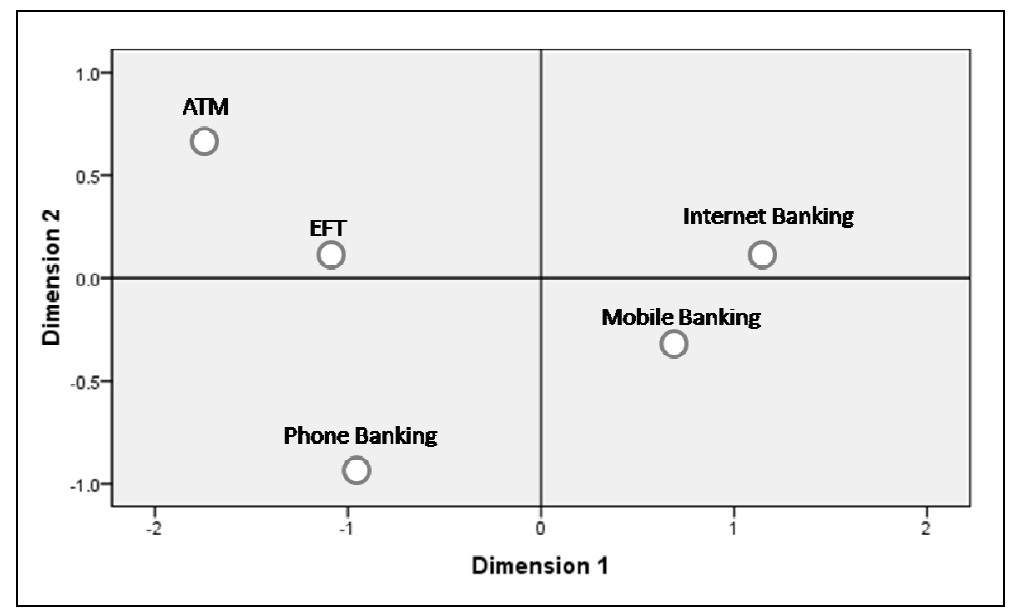

Figure 1. Initial model

This initial model was subject to reliability \& validity assessment using S-stress and R-squared. S-stress value was 0.078 (< 0.1 acceptable; Blake et al., 2003) and R-squared value was 0.906 ( $>0.6$ acceptable; Malhotra \& Dash, 2011). Further, in scatter plot of the initial model (Figure 2) all points were forming almost a straight line and according to Blake et al. (2003) this reflects good model fit. Hence, initial model was accepted. Subsequently in the initial model, labeling of the two dimensions was done with relevant criteria. Respondents' ranking of 5 objects on these 7 criteria viz. complexity (coded as 1), accessibility (2), cost (3), accuracy (4), security (5), usefulness (6), privacy (7) were used to statistically label the dimension using linear regression analysis. Figure 3 depicts fitting of 7 criteria vectors along with axes in the initial model.

Figure 3 clearly depicts that there are two groups of criteria pertaining to e-banking channels. First group includes criterion 4 (accuracy), 2 (accessibility), 6 (usefulness), which are all pointed in same direction, and criterion 1 (complexity), 3 (cost) which are in the opposite direction. This directional difference indicates a negative correspondence of cost and complexity versus the three other variables. This finding is logically more coherent in context of usefulness of e-banking channel. Technology Acceptance Model (TAM), which explains users' adoption of a technology (like e-banking) proposes that ease of use positively affect usefulness (Davis, 1989), thus TAM validates the above findings. Complexity is just opposite of ease of use, which is found to be 
negatively affecting usefulness of e-banking channels in perceptual map. Similarly, cost is in negative correspondence versus usefulness. This indicates that as cost incurred in using e-banking services increases, its usefulness declines. Further, uni-directionality of usefulness, accuracy and accessibility indicates that accuracy and accessibility offered by e-banking channels add to channel usefulness.

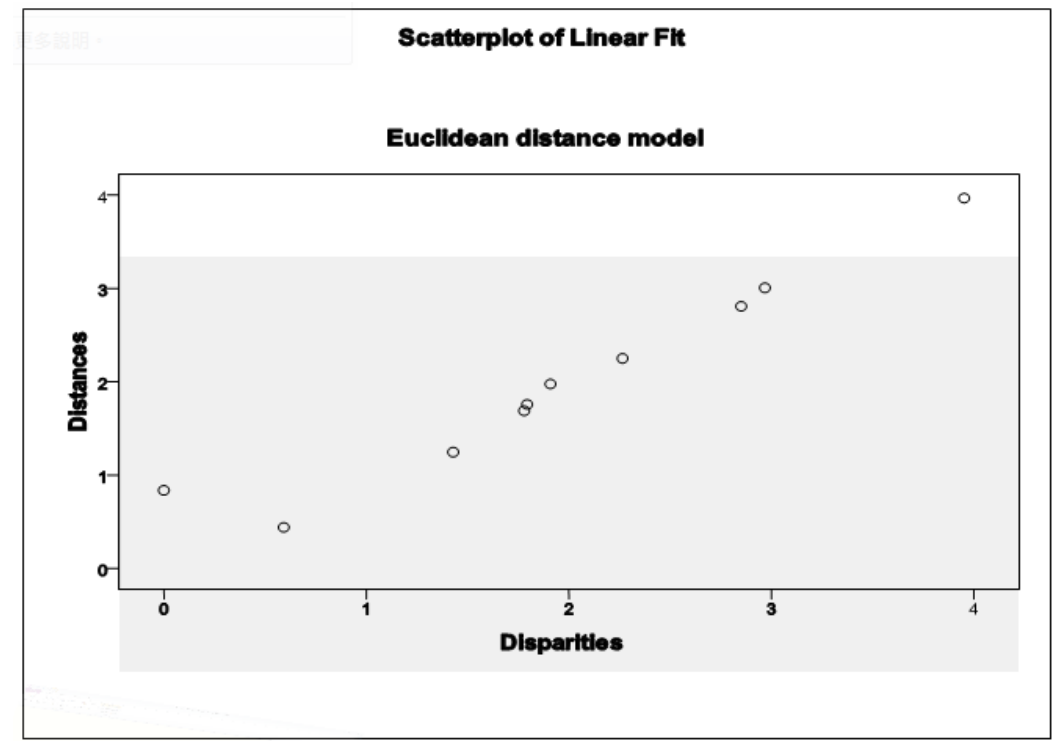

Figure 2. Scatter plot of linear fit

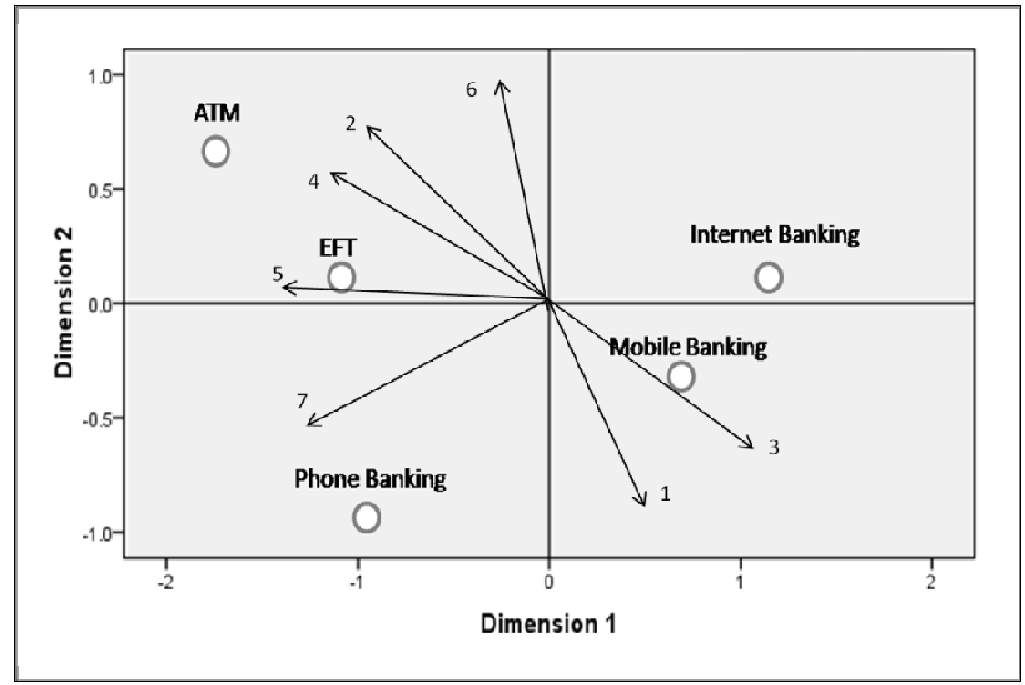

Figure 3. Statistical labeling of dimensions

Second group includes criterion 5 (security) and 7 (privacy). Privacy is almost perpendicular to all criteria pertaining to first group, indicating a separate and distinct evaluative dimension. Up to some extent same case is applicable to security criteria.

In perceptual map, axes may be labeled for the criterion which they tightly align; resulting in labeling of dimensions (Malhotra \& Dash, 2011). So x-axis of e-banking perceptual map (i.e. dimension 2) was labeled as security. Steyvers (2002) suggested that perceptual map is a point representation and its axes can be rotated without any impact on the relative positions of objects. So to configure the 2 nd dimension of perceptual map, axes were rotated slightly towards right. This resulted in y-axis (i.e. dimension 1) getting aligned with criterion 6 (usefulness) and 1 (complexity). Hence, dimension 1 of e-banking perceptual map was labeled as usefulness vs. 
complexity (Figure 4).

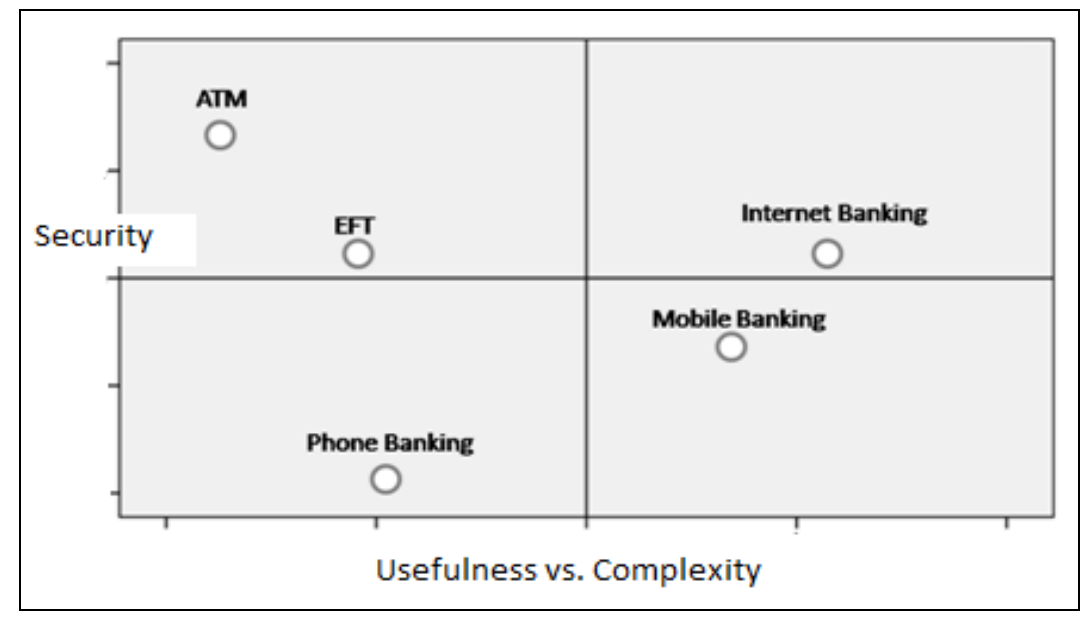

Figure 4. Final model

Final model duly labeled (Figure 4) suggests that ATM has distinct position on perceptual map and is considered to be most secure among all e-banking channels. Further, ATM tops on 'high usefulness \& low complexity' dimension. Past studies based on adoption and penetration of ATMs in India (Rishi \& Saxena, 2004; Kumar et al., 2011), also support this finding. Although phone banking perceived secure, however, very low on usefulness. Study by Shambare (2011) validates this finding. This study stated that phone banking in S. Africa, is perceived to be very complex even for simple transactions link a/c balance check and of low relative advantage (usefulness). Further, Internet banking and mobile banking occupied close position on perceptual map. Internet banking was perceived to be lowest on security, followed by mobile banking. But on usefulness dimension, internet baking has more positive perception. EFT was the e-banking channel in most close proximity of ATM and was perceived to be reasonably secure and useful. This finding has some discrepancy; as if EFT is perceived reasonably secure as well as useful it must have decently penetrated in India. But statistics suggest otherwise, where penetration of EFT in India is not even in single digit in percentage term (Puri, 2011). Overall, Figure 4 implies that barring ATM and rest of the e-banking channels are lagging on at least one of the two derived dimensions viz. security and usefulness vs. complexity.

\section{Conclusions}

To cut rising operational costs and to reach broader customer base, banks need successfully implementation $\&$ subsequent integration various e-banking channels. For this, banks must understand customers' perceptions towards various e-banking channels and their underlying motives to choose \& prefer one channel over other. The study empirically developed a perceptual map of select active e-banking channels available in India (viz. ATM, EFT, phone banking, internet banking and mobile banking) and derived relevant dimensions which influence above perception. Using dissimilarity data collected from 468 respondents, this study employed Multidimensional Scaling (MDS) technique to develop a two dimensional perceptual map. Subsequently using statistical method, above map was labeled where one dimension was derived to be security and other was usefulness vs. complexity. ATM was distinctly placed on perceptual map and was positioned as most secure \& useful among e-banking channels. Phone banking was perceived to be low on usefulness and high on complexity. Mobile banking and internet banking were closely placed and both were perceived to be less secure. Findings highlighted areas of improvements for e-banking channels.

\subsection{Implications}

Further, this study derived some useful action points on the basis of perceptual map, which could help India banks to promote e-banking services. ATM as an e-banking channel was high on both security and usefulness vs. 
complexity. Definitely, ATMs have established themselves in India in the past decade. Looking at the higher acceptance level of ATM technology in India, marketers should focus on some incremental innovations to delivery advance services through ATMs, so that to create value for customers and reduce operational cost. In some other parts of the world, ATMs are ready for the leap to such innovations e. g. Video Teller Machine, an ATM which integrates videoconferencing technology, document scanners, card readers and printers to support rich communication between the customer and the bank. Such remote banking system could allow customers to complete sophisticated transactions remotely through online consultation with an expert from the bank (Jhingan, 2012). In case of mobile banking and internet banking, banks need to raise awareness about benefits of these e-banking channels and at same time need to mitigate security issues.

As Bamoriya and Singh (2011) stated that in India interoperability of mobile banking services offered by different banks, is one of the major issues deterring mass adoption of this channel. This lack of interoperability could be the reason due to mobile banking channel is perceived less useful in comparison to channel like ATM, as the current study suggests. Hence, banks should work on interoperability issue both at network level and at base technology level viz. J2ME (Java 2 Micro Edition), USSD (Unstructured Supplementary Services Data), IVR (Interactive Voice Response service), SMS (Short Message Service), WAP (Wireless Access Protocol). For example, in case for mobile banking services offered via SMS; all banks could adopt common ISO 8583 message format to ensure interoperability among banks and support customers across banks. Still not all Indian banks are using 128 bit SSL (Secure Socket Layer) encryption or more, in mobile banking and internet banking which poses risk of data transmitted being intercepted (RBI Publication, 2011). It should make it mandatory for the banks to apply at least 128 bit SSL encryption, so that these two e-banking channels will become more secure and will see more favorable adoption by customers.

Further to add in security issues involving encryption, while offering services through internet banking and WAP based mobile banking; banks should opt for VeriSign verification and certification. The derived dimensions for e-banking viz. usefulness, complexity and security; also have element of customer perception involved (Geetha \& Malarvizhi, 2011). So banks should attempt raising awareness of what an e-banking can do \& what not, how to do it and what are the functional risks. A special task force should be trained by banks specifically to pass on the knowledge to the users to tackle technical illiteracy issue so as to reduce complexity and enhance security perception. Ultimate objective of banks and regulators should be to pave the path for more cost effective, efficient, ubiquitous and convenient e-banking solutions.

\subsection{Limitations and scope for future research}

A suggested guideline for stable solutions is to have more than four times as many objects as dimensions desired (Blake et al. 2003). But by this criteria study involved insufficient number of objects (total five) which may lead to some validity issues in perceptual map generated. Second limitation of study was due to time \& resource constrain, where data at two different points in time was not collected \& test-retest reliability was not determined. At last, the proposed methodology of this study suffers from the inherent limitations as all MDS models, in terms of dimension reduction.

Future research could focus on developing a preference map for same five e-banking channels and could identify ideal point through it. This ideal point of e-banking could serve as useful guide to banks in improving quality of e-banking services. Further, more extensive testing of the procedure and comparisons with alternative latent-class MDS models would be desirable through rigorous Monte Carlo testing. So future research should focus on above methodological aspect. At last, future research could use a multiple correspondence analysis to explore the relationships various e-banking channels and their service attributes. This can help banks gain insights into their key services attributes and their customers. 


\section{References}

Adapa, S., Rindfleish, J., Cooksey, R., \& Valenzuela, F. (2009). An empirical investigation of frequency of internet banking usage by Australian consumers. Retrieved June 11, 2010, from http://www.duplication.net.au/ANZMAC09/papers/ANZMAC2009-549.pdf

Aladwani, A. (2001). Online banking: a field study of drivers, development challenges and expectations. International Journal of Information Management, 21(3), 213-25. http://dx.doi.org/10.1016/S0268-4012(01)00011-1

Alagheband, P. (2006). Adoption of electronic banking services by Iranian customers. Retrieved June 12, 2011, http://epubl.luth.se/1653-0187/2006/49/LTU-PB-EX-0649-SE.pdf

Aliyu, A., Younus, S., \& Tasmin, R. (2012). An exploratory study on adoption of electronic banking: underlying consumer behaviour and critical success factors- case of Nigeria. Business and Management Review, 2(1), 01-06.

Almazari, A. A. K., \& Siam, A. Z. (2008). E-Banking: An empirical study on the Jordanian commercial banks. Journal of King Abdul-Aziz University, 22(2), 3-26.

Al-Smadi, M. O. (2012). Factors affecting adoption of electronic banking: an analysis of the perspectives of banks' customers. International Journal of Business and Social Science, 3(17), 294-309.

Al-Smadi, M. O., \& Al-Wabel, S. A. (2011). The impact of e-banking on the performance of Jordanian banks. Journal of Internet Banking and Commerce, 16(2), 1-10.

Anguelov, C. E., Hilgert, M. A., \& Hogarth, J. M. (2004). U.S. consumers and electronic banking. The Federal Reserve Board, Issue 1995-2003.

Ayrga, A. (2011). Is Mauritius ready to e-bank? From a customer and banking perspective. Journal of Internet Banking and Commerce, 16(1), 1-17.

Bamoriya, Prerna (2010). Service quality perception in online banking: a comparative study of online banking users of public and private banks. Knowledge Hub, 6(2), 174-181.

Bamoriya, Prerna Sharma, \& Singh, P. (2011). Issues and challenges in mobile banking in India: a customers' perspective. Retrieved February 13, 2012, from http://www.iiste.org/Journals/index.php/RJFA/article/view/189/73

Blake, B. F., Schulze, S., \& Hughes, J. (2003). Perceptual mapping by Multidimensional Scaling: A step by step primer. Research Reports in Consumer Behavior, September 2003 issue.

Calisir, F., \& Gumussoy, C. (2008). Internet banking versus other banking channels: young consumers' view. International Journal of Information Management, 28, 215-221.

http://dx.doi.org/10.1016/j.ijinfomgt.2008.02.009

Centeno, C. (2004). Adoption of internet services in the acceding and candidate countries, lessons from the internet banking case. Telematics and Informatics, 21, 293-315. http://dx.doi.org/10.1016/j.tele.2004.02.001

Chang, Y. (2002). Dynamics of banking technology adoption: An application to internet banking. Retrieved February 21, 2012, from http://repec.org/res2003/Chang.pdf

Davis, F. D. (1989). Perceived usefulness, perceived ease of use, and user acceptance of information technology. MIS Quarterly, 319-339. http://dx.doi.org/10.2307/249008

Geetha, K. T., \& Malarvizhi, V. (2011). Acceptance of e-banking among customers: an empirical investigation in India. Journal of Management and Science, 2(1), 1-9.

Gerrard, P., Cunningham, J. B., \& Devlin, J. F. (2006). Why consumers are not using internet banking: a qualitative study. Journal of Services Marketing, 20(3), 160-168.

http://dx.doi.org/10.1108/08876040610665616

Jasmina, B., \& Vlahov, K. D. (2011). A Logit model of electronic banking adoption: The case of Komercijalna Banka AD Skopje. Retrieved March 11, 2012, http://www.isi2011.congressplanner.eu/pdfs/950580.pdf

Jhingan, H. (2012). Digital channels enter banking mainstream. Retrieved October 30, 2012, http://computer.financialexpress.com/features/611-digital-channels-enter-banking-mainstream

Joshua, A. J., \& Koshy, M. (2011). Usages patterns of electronic banking services by urban educated customers: 
Bamoriya, P., Bamoriya, H., \& Singh, P.

Glimpses from India. Journal of Internet Banking and Commerce, 16(1), 1-12.

Kessler, S. (2011). Why the Web is useless in developing countries - and how to fix it. Retrieved March 01, 2012, http://mashable.com/2011/02/04/web-developing-world/

Kohli, C. S., \& Leuthesser, L. (1993). Product positioning: A comparison of perceptual mapping techniques. Journal of Product \& Brand Management, 2, 10-20. http://dx.doi.org/10.1108/10610429310047660

Kolodinsky, J. M., Hogarth, J. M., \& Hilgert, M. A. (2004).The adoption of electronic banking technologies by US consumers. Retrieved September 12, 2012, http:// www.emeraldinsight.com/0265-2323.htm

Kruskal, J. B., \& Wish, M. (1978). Multidimensional Scaling. Sage Pub, California.

Kumar, Lakshmi, Malathy, D., \& Ganesh, L. S. (2011). The diffusion of ATM technology in Indian banking. Retrieved March 11, 2012, http://www.hull.ac.uk/php/ecskrb/med2007/Lakshmi.5144.1182929606

Kumar, S., \& Garg, R. (2012). Service quality measurement of internet banking: A customers' perspective. Retrieved June 16, 2012, https://www.uop.edu.jo/download/Research/members/488_2251_khal.doc

Malhotra, N. K., \& Dash, S. (Ed.). (2011). Marketing research: an applied orientation. New Delhi: Pearson Pub.

Mols, N. P. (1999). The internet and the banks'strategic distribution channel decisions. http://dx.doi.org/10.1108/02652329910300341

Nitsure, R. R. (2003). E-banking: challenges and opportunities. Economic and Political Weekly, 38(51/52), 5377-5381.

O'Connell, B. (1996). Australian banking on the internet- fact or fiction?. The Australian Banker, (December), 212-214.

Prakash, A., \& Malik, G. (2008). Empirical study of internet banking in India. Internet research, 12(5), 83-92.

Puri, A. (2011). Towards a highway for money. Retrieved June 13, 2011, from http://www.livemint.com/Opinion/JRdLZKaMvJWjQaI2GFO3vK/Towards-a-highway-for-money.html

RBI Publication (2011). Report on internet banking. Retrieved Oct 28, 2011, from http://rbidocs.rbi.org.in/rdocs/PublicationReport/Pdfs/21595.pdf

Rishi, M., \& Saxena, S. C. (2004). Technological innovations in Indian banking industry: the Late Bloomer. Accounting Business and Finance History, 14(3), 339-353. http://dx.doi.org/10.1080/0958520042000277801

Sadeghi, T., \& Heidarzadeh, H. K. (2010). Customer Satisfaction Factors (CSFs) with online banking services in an Islamic Country. Iranian Journal of Islamic Marketing, 1(3), 249-267. http://dx.doi.org/10.1108/17590831011082428

Saxena, A. (2009). Accelerating financial inclusion through innovative channels: 10 obstacles for mfis launching alternative channels. Retrieved Oct 29, 2011, http://www.gsma.com/mobilefordevelopment/wp-content/uploads/2012/03/insight26.pdf

Shambare, R. (2011). Cell phone banking adoption in South Africa. Business and Economic Research, 1(1), $1-15$.

Steyvers, M. (2002). Multidimensional Scaling. Encyclopedia of Cognitive Science, 1-5.

VanHoose, D. (2003). E-commerce economics. Thomson Learning, Ohio: South-Western.

Wessels L., \& Drennan, J. (2010). An investigation of consumer acceptance of m-banking. International Journal of Bank Marketing, 28(7), 547-568. http://dx.doi.org/10.1108/02652321011085194 